\title{
IbM PADA IBU-IBU TIM PENGGERAK PKK KOTA MANADO MELALUI PELATIHAN PENGELOLAAN INTERNET SEBAGAI SUMBER INFORMASI UNTUK KELUARGA DAN PELUANG WIRAUSAHA
}

\author{
Julyeta Paulina Amelia Runtuwene \\ Program Studi Teknik Informatika, Fakultas Teknik, Universitas Negeri Manado (UNIMA) \\ ingeridmoniaga73@gmail.com; amandasembel@gmail.com
}

\begin{abstract}
Abstrak
Telah dilakukan pengabdian pada masyarakat program Ipteks bagi masyarakat (IbM) dari Lembaga Pengabdian Pada Masyarakat (LPPM) Program Studi Pendidikan Teknik Informasi dan Komunikasi Fakultas Teknik Universitas Negeri Manado dengan kegiatan Pelatihan Pengelolaan Internet Sebagai Sumber Informasi Untuk Keluarga dan Peluang Wirausaha pada Ibu-Ibu Kader Tim penggerak PKK se-Kota Manado. Dampak pengiring dari program pelaksanaan ipteks bagi IbM bagi masyarakat ini adalah munculnya kesadaran bagi Ibu-Ibu Rumah tangga se-Kota Manado tentang bahaya internet yang tidak digunakan dengan baik. Selanjutnya dampak lain adalah munculnya kesadaran bahwa dengan internet, Ibu-Ibu dapat melakukan usaha promosi produk jualan ataupun produk hasil karya sendiri.

Pelaksanaan program IbM ini dilakukan secara bermitra dengan para Ketua TP PKK Kecamatan se-Kota Manado. Permasalahan yang dihadapi para Ibu lulusan program pelatihan Rumah Pintar adalah kurangnya informasi pemasaran produk. Metode pelaksanaan kegiatan dibagi dalam 3 tahap kegiatan; masing-masing tahap identifikasi permasalahan; dan tahap pelaksanaan kegiatan berupa seminar, pelatihan dan praktikum.

Hasil dari kegiatan yang dilakukan menunjukkan partisipasi aktif dari para Ibu dalam memahami materi yang diberikan. Pemanfaatan internet sebagai peluang usaha baru juga mendapat perhatian yang serius dari para Ibu. Dalam pelatihan ini telah dilakukan pembuatan dan perancangan "media sosial" yang menarik untuk promosi produk.
\end{abstract}

Kata Kunci: internet, sumber informasi, peluang wirausaha.

\section{PENDAHULUAN}

\section{Analisis Situasi}

Perkembangan ilmu dan teknologi yang sangat cepat dan sangat mudah diakses dengan biaya yang juga murah seringkali membawa perubahan dalam tatanan kehidupan masyarakat. Salah satu perubahan yang dengan jelas terlihat adalah informasi yang dengan mudah dan cepat beredar dari seluruh dunia. Sebagai contoh terjadinya banjir bandang di Kota Manado pada tanggal 15 januari 2014 lalu dalam hitungan detik langsung diketahui di belahan dunia lain, ketika masyarakat yang terhubung dalam suatu link komunikasi dengan cepat menyebarkan berita tersebut. Sistem komunikasi melalui internet maupun pesan singkat berkelompok yang semakin berkembang (contohnya blackberry messenger, whatsup, line, dll) mampu mempersingkat jarak dan waktu antara manusia yang dipisahkan oleh benua.

Teknologi informasi dan komunikasi yang semakin modern, semakin gampang didapat dan bisa diakses kapan saja dan dimana saja serta semakin murah merupakan faktor pendukung pesatnya peredaran informasi. Mencermati perkembangan teknologi informasi dan komunikasi yang 
terjadi, terlihat tahapan-tahapan yang cukup mencengangkan. Jika dulu ketika berkomunikasi dengan telephone, jarak yang jauh akan semakin mempertinggi biaya yang harus dikeluarkan. Selanjutnya munculnya internet memperkecil biaya tersebut, tetapi orang masih harus menggunakan komputer ketika berkomunikasi. Gabungan kedua teknologi ini melahirkan telephone smart yang mampu diakses dimana saja dengan biaya yang murah. Saat ini berbagai provider telephone menawarkan akses internet tanpa batas, sehingga komunikasi yang berjalan bukan saja hanya melalui suara tetapi mampu melakukan tele conference sehingga komunikasi terasa tanpa batas.

Selain sebagai fungsi komunikasi dua arah, perkembangan teknologi handphone telah memungkinkan komunikasi dan informasi tersebar luas tanpa batas. Laju teknologi smart phone yang sangat cepat telah sanggup merubah gaya komunikasi manusia termasuk Ibu-Ibu Rumah Tangga Morahan-Martin, 2004). Penggunaan smart phone yang tadinya hanya sebagai alat komunikasi biasa juga menjadi berkembang sebagai bagian dari gaya hidup. Keberadaanya tidak dapat dipisahkan dengan simbol status sosial dan ekonomi, ataupun menjadi lambang kebanggaan suatu kalangan tertentu yang menggunakannya. Sebagian orang bahkan menciptakan gaya hidup tampil beda dengan berusaha mencari sesuatu yang berbeda dengan orang lain. Seperti halnya makan, minum, rumah, mobil, liburan, saat ini masyarakat tidak dapat lepas juga dari handphone di masyarakat. Salah satu factor menguntungkan dengan kondisi ini adalah akses informasi kesehatan wanita yang lebih terbuka dengan adanya internet. Penelitian Forgel et al. (2002) menunjukkan bahwa lebih dari 40\% dari 188 perempuan yang disuvei menggunakan internet untuk mendapatkan informasi kesehatan terutama yang berhubungan dengan kanker payudara. Selanjutnya Rodgers and Chen (2005) melakukan analisis pada 33.000 posting internet dan menemukan bahwa terdapat korelasi positif antara perempuan yang terkena kanker payudara dengan keaktifan dalam kelompok internet, dimana keaktifan dalam kelompok ini mampu memberikan motivasi, meningkatkan ketrampilan mengelola penyakit, menekan stress, dan berbagi informasi. Penggunaa internet di kalangan Ibu-Ibu Rumah Tangga juga dilaporkan mampu memberikan kontribusi dalam mengasuh anak, terutama pada IbuIbu yang memiliki anak di bawah umum (Drente and Moren-Cross, 2005). Selain itu, penggunaan internet untuk berwirausaha juga menjadi datya Tarik tersendiri. Internet dengan segala kemampuannya mendekatkan yang jauh dapat menjadi sarana informasi menjual produk yang diproduksi dalam skala rumah tangga. Saat ini media social seperti facebook menjadi ajang informasi bagi produk yang ditawarkan. Kementerian Perindustrian dan 
Perdagangan Republik Indonesia secara khusus telah membuat aplikasi e-commerse yang berhubungan dengan penjualan produk kreatifitas skala rumah tangga untuk ditawarkan sampai ke seluruh dunia.

Selain sisi positif penggunaan internet, sisi negative juga semakin meningkat, terutama pada anak usia dini. Penelitian Lee and Chae (2007) pada anakanak usia sekolah di Korea menunjukkan tingkat penggunaan internet yang meningkat mempengaruhi jumlah dan waktu bersama keluarga, sementara pembatasan jam internet pada anak-anak tidak mempengaruhi tingkat kecanduan tersebut. Sisi negative ini pada akhirnya akan mempengaruhi kualitas hubungan keluarga, terutama antara anak dan orangtua.

Tim Penggerak Pemberdayaan Kesejahteraan Keluarga Kota Manado sebagian besar adalah terdiri dari Ibu-Ibu yang bertanggung jawab dalam hampir keseluruhan pengelolaan rumah tangga, termasuk didalamnya anak. Saat ini kemampuan penggunaan internet pada Ibu-Ibu masih terbatas pada penggunaan untuk menjalin silaturahmi dengan kerabat dan teman. Penggunaan internet untuk mendapatkan informasi kesehatan masih kurang dilakukan dan jikapun ada masih terbatas pada informasi yang dibagikan dari grupgrup social media yang seringkali tidak bisa dijamin kebenarannya. Kurangnya penguasaan initernet ini menjadi kendala ketika Ibu-Ibu dengan gampang juga ikut men-share informasi yang keakuratannya tidak bisa dijamin. Untuk itu diperlukan pelatihan ketrampilan dalam memanfaatkan internet bagi Ibu-Ibu Rumah Tangga di Kota Manado.

\section{Permasalahan Mitra}

Berdasarkan hasil diskusi dan pengamatan pada Ibu-Ibu Rumah Tangga di Kota Manado, dapat diidentifikasi beberapa permasalahan sebagai berikut:

1. Kurangnya pemahaman akan pemanfaatan internet yang baik.

2. Kesulitan Ibu-Ibu dalam mengejar pengetahuan internet anak sehingga tidak bisa melakukan pendampingan ketika anak harus mengerjakan tugas yang membutuhkan penggunaan internet.

3. Belum pahamnya Ibu-Ibu tentang bagaimana memilah informasi yang dibagikan melalui media social secara sembarangan

4. Tidak pahamnya Ibu-Ibu dalam memproteksi anak terhadap bahaya fisik dan psikis internet.

\section{METODE PELAKSANAAN}

Berdasarkan permasalahan mitra yang teridentifikasi pada bagian sebelumnya, maka solusi yang ditawarkan dalam kegiatan Ipteks bagi masyarakat LPPM Universitas Negeri Manado adalah kegiatan pembimbingan bagi Ibu-Ibu Rumaha Tangga di Kota Manado dalam upaya peningkatan pemahaman tentang 
penggunaan internet khususnya dalam memberikan informasi dan pengetahuan praktis yang bisa dimanfaatkan Ibu-Ibu Rumah Tangga dalam pembimbingan anak, pengelolaan rumah tangga bahkan sampai pada taraf wirausaha. Pelaksanaan program Ipteks bagi masyarakat (IbM) ini dilakukan secara bermitra dengan para Ketua Tim Penggerak PKK Kecamatan se-Kota Manado diwakili oleh Ketua TP PKK Kecamatan Wenang (Mitra 1) dan Ketua TP PKK Kecamatan Paal 2 (Mitra 2). Peran para Mitra adalah memberikan informasi dan data tentang keadaan dan permasalahan yang dihadapi Ibu-Ibu Rumah Tangga sehubungan dengan semakin maraknya penggunaan internet di kalangan anak-anak dan perlunya pengetahuan tambahan bagi Ibu-Ibu Rumah Tangga tentang bagaimana mengantisipasi informasi dari internet.

Agar pelaksanaan IbM dapat berjalan dengan lanjar, maka pelaksanaan dibagi dalam beberapa tahap, masingmasing:

1. Tahap identifikasi permasalahan yang banyak terjadi dan kesulitan yang berhubungan dengan penggunaan internet di kalangan Ibu-Ibu dan anakanak di Kota Manado.

2. Tahap pelaksanaan pelatihan penggunaan internet yang baik dan cara pemanfaatan internet untuk wirausaha.

3. Tahap penyusunan petunjuk penggunaan internet yang aman dan berguna bagi rumah tangga.
Untuk berjalannya pelaksanaan kegiatan dengan baik, maka langkahlangkah yang akan dilakukan adalah:

1. Tahap awal seminar proposal dan perizinan.

2. Tahap persiapan.

3. Tahap pelaksanaan, berupa : seminar, pelatihan, diskusi, tanya jawab dan praktek penggunaan internet.

4. Tahap pendampingan praktek browsing untuk pencarian informasi

5. Evaluasi, seminar hasil kegiatan, dan pembuatan laporan.

\section{HASIL DAN PEMBAHASAN}

Gerakan Pemberdayaan Kesejahteraan Keluarga (PKK) sebagai gerakan nasional dalam pembangunan masyarakat yang tumbuh dari bawah yang pengelolaannya dari, oleh dan untuk masyarakat menuju terwujudnya keluarga yang beriman dan bertaqwa kepada Tuhan Yang Mahaesa, berakhlak mulia dan berbudi luhur, sehat sejahtera, maju dan mandiri, kesetaraan dan keadilan gender serta kesadaran hukum dan lingkungan. Selanjut-nya dikatakan bahwa pemberdayaan keluarga adalah segala upaya bimbingan dan pembinaan agar keluarga dapat hidup sehat sejahtera, maju dan mandiri. Sesuai dengan prinsipnya sebagai gerakan pemberdayaan dan partisipasi masyarakat, sifat gerakan PKK adalah universal dan independent dimana penyelenggaraannya dilandasi dengan peraturan perundang-undangan. 
Dalam pelaksanaan kegiatan Tim Penggerak PKK Kota Manado berperan sebagai motivator, fasilitator, perencana, pelaksana, pengendali dan penggerak. Selanjutnya pembinaan teknis kepada keluarga dan masyarakat dilaksanakan dalam kerjasama dengan unsur dinas instansi pemerintah terkait.

Kesadaran bahwa internet sudah menjadi bagian yang tidak terpisahkan bagi banyak orang dan para ibu-ibu rumah tanggapun tidak luput dari jerat pesonanya. Dengan perkembangan teknologi komunikasi yang super canggih, sangatlah mudah bagi kita untuk memiliki smartphone ataupun tablet. Smartphone mahal menjadi mainan Ibu-Ibu dan anak kecil, dan berbekal gadget keren inilah ibu-ibu memulai petualangan di dunia maya. Ibu-Ibu juga sangat membutuhkan internet demi membantu aktivitas sehari-hari dan mereka juga butuh media untuk berkomunikasi dengan rekan sesama ibu rumah tangga.

Selain itu keterhubungan global (global connectivity) melalui Internet dan kemudahan penggunaan (ease of use) dapat menyediakan akses kepada dunia bisnis dan perorangan yang secara normal akan sulit dilakukan. Perusahaan bisnis dapat secara langsung menghubungi kepada pemasok, rekan bisnis, atau pelanggan perorangan dengan biaya rendah, meskipun terletak sangat jauh secara geografis. Pengusaha dapat mencari outlet baru untuk produk atau jasa yang ditawarkannya secara lebih luas karena Internet memfasilitasi transaksi silang batas (cross-border transactions) dan informasi mengalir lebih cepat. Selain itu, Internet juga menyediakan media yang berbiaya rendah (low cost medium) bagi aliansi global dan organisasi maya (virtual organizations). Web merupakan antar muka (interface) standar dengan media Internet dan memungkinkan akses global dengan murah yang dapat digunakan untuk menciptakan sistem dalam organisasi.

Internet membawa perubahan cukup besar terhadap bisnis dan melahirkan istilah yang disebut e-business. Kotler (2003) mendefinisikan e-business sebagai "penggunaan alat dan platform elektronis untuk melaksanakan bisnis perusahaan". Secara lebih jelas, O'Brien (2001) mendefinisikannya sebagai "penggunaan teknologi-teknologi Internet untuk menghubungkan dan memberdayakan proses bisnis, perdagangan elektronis, dan komunikasi serta kolaborasi di dalam sebuah perusahaan dan dengan para pelanggan, pemasok, dan mitra bisnis yang lain".

Dalam kegiatan pengabdian ini peserta digolongkan dalam beberapa kelompok, menurut tingkat penggunaan internet. Kelompok ahli, dipisahkan sendiri untuk lebih memudahkan, sementara IbuIbu yang sama sekali tidak bisa menggunakan internet dikelompokkan secara terpisah. Pada kelompok yang tidak bisa sama sekali, dilakukan beberapa kali pengajaran sampai para Ibu bisa 
mengaplikasikan ilmu yang diajarkan. Untuk keterbatasan layanan internet dilakukan pembukaan jaringan dari smartphone yang memiliki paket data. Selain itu koordinasi dengan pemerintah Kecamatan se-Kota Manado juga terus dengan memberikan waktu untuk pendampingan pada Ibu-Ibu Kader PKK ketika melaksanakan penyuluhan dan praktek kepada Ibu-Ibu Rumah Tangga di lingkungan masing-masing.

Penyuluhan dilakukan dengan melakukan seminar Internet Sehat dan Internet Sebagai Media Bisnis Baru serta melakukan praktek cara mengelola internet sehat dan promosi melalui internet. Awalnya dilakukan seminar untuk memberikan pemahaman kepada para IbuIbu Kader PKK bagaimana tanggung jawab dalam menggunakan internet. Hal ini terutama berhubungan dengan pengaruh konten negatif yang sudah sering diberitakan di berbagai media berupa pemuatan gambar porno, perjudian, penipuan, pelecehan, pencemaran nama baik dan berita bohong. Selain itu penggunaan jejaring sosial juga memiliki dampak negatif, salah satunya adalah cyberbullying yang biasanya menimpa anak-anak dan sesama remaja. Bahkan kejahatan dunia maya yang dikenal sebagai cybercrime sudah sampai pada peretasan situs-situs penting dalam negeri.

Selanjutnya pada materi Internet untuk bisnis dijelaskan tentang bagaimana menggunakan internet sebagai cara pemasaran produk. TP PKK Kota Manado melalui Pokja 2 selama ini mengelola Rumah Pintar yang menyelenggarakan berbagai pelatihan ketrampilan bagi Ibu-Ibu Rumah Tangga dengan sasaran agar para Ibu mendapatkan penghasilan tambahan. Pelatihan yang dilakukan di Rumah Pintar TP PKK Kota Manado antara lain latihan menjahit, membuat aneka pangan/snack, latihan tata rias, dan lain-lain. Selama ini TP PKK Kota Manado belum mempunyai divisi penjualan hasil karya Ibu-Ibu yang telah lulus pelatihan.

\section{KESIMPULAN}

Kegiatan pengabdian pada masyarakat untuk penerapan IPTEKS bagi masyarakat yang telah dilakukan pada dasarnya dapat berjalan dengan baik, dengan adanya kesadaran berinternet sehat dan adanya kemampuan Ibu-Ibu dalam memanfaatan internet untuk pemasaran produk. Dibutuhkan kegiatan lanjutan berupa pelatihan pembuatan website terpadu bagi TP PKK Kota Manado untuk menampung produk rumah tangga Ibu-Ibu PKK Kota Manado

\section{KEPUSTAKAAN}

Fogel, J., Albert, S.M., Schnabel, F., Ditkoff, B.A.and Neugut, A.I. 2002. Internet use and social support in women with breast cancer. Health Psychology, Volume 21 No.4.p398-404.

Dreanthea, P and Moren-Cross, J.L. 2005. Social capital and social support on the web: the case of an internet mother site. 
Journal of Sosiology of Health and Illness. Volume 27, Issue 7. p920-943

Morahan-Martin, J. 2004. Women and the Internet: Promise and Perils. CyberPsychology \& Behavior. Volume: 3 Issue 5.

Lee, S and Chae, Y. 2007. Children's Internet Use in a Family Context: Influence on Family Relationships and Parental
Mediation. Cyber Psychology and Behavior. Volume: 10 Issue 5. p640-644.

Rodgers, S and Chen, Q. 2005. Internet Community Group Participation: Psychosocial Benefits for Women with Breast Cancer. Journal of Computer Mediated Communication. Volume 10, Issue 4 
Jurnal ABDIMAS, Vol. 11, No. 2, Agustus 2018

ISSN: 1979-0953 | e-ISSN: 2598-6066 